\title{
Should Teaching be Re(dis)covered? Introduction to a Symposium
}

\author{
Gert Biesta $^{1}$ \\ Published online: 6 June 2019 \\ (c) Springer Nature B.V. 2019
}

In 2017 I published a book with the title The Rediscovery of Teaching (Biesta 2017). In this book, as the title suggests, I give an affirmative answer to the question as to whether teaching should be re(dis)covered. I partly do this in response to the ongoing 'learnification' (Biesta 2010) of education, that is, the redefinition of all things educational in terms of learning - such as calling students learners, calling schools learning environments or places for learning, referring to adult education as lifelong learning, and seeing teachers as facilitators of learning.

The shift from teaching to learning has not just affected the language of education, but has also impacted on the role, position and even the identity of the teacher. Here we see a shift from the teacher as a 'sage on the stage' to that of a 'guide on the side,' and, according to some, even to that of a 'peer at the rear,' ${ }^{1}$ - the teacher as a learner amongst other learners in a learning community, (almost) undistinguishable from their students. The book is also meant as a response to this development. Some see the shifting position of the teacher as desirable and are happy to move the teacher to this place or, as teacher, are happy to move themselves to that place. Others see it as a loss, but struggle to find a meaningful response, other than by returning the teacher 'centre stage,' so to speak.

The book seeks to make an intervention in this situation, not just in response to the marginalisation of teaching and the teacher, but also in response to recent developments that seem to hail the return of the teacher. Recent documents, for example from the OECD, the Worldbank and McKinsey, argue that teaching matters because research apparently has shown that the teacher is the most important factor in the production of the learning outcomes that such organisations highlight as being crucial in education. Yet rather than seeing this as a rehabilitation of teaching and teachers, I tend to think of this differently. I neither think that the teacher is a factor, nor that education is a matter of production. I also have doubts about the validity of the 'learning outcomes,' if such a phrase even makes sense, that seem to be valued in these discussions. Seeing teachers as factors in a production-line is in my view an insult to the integrity of teacher professionalism, not a way to enhance it.

\footnotetext{
${ }^{1}$ I thank Norm Friesen for alerting me to this expression.
}

\section{Gert Biesta}

gert.biesta@mu.ie

1 Centre for Public Education and Pedagogy, Maynooth University, Maynooth, Co. Kildare, Ireland 


\section{From Teaching as Control to Learning as Freedom?}

In the background of these developments is a discussion which at least goes back to Paolo Freire's critique of 'banking education,' that is, the mode of education where students are turned into "'receptacles' to be 'filled' by the teacher" and where teaching becomes an "act of depositing, in which the students are the depositories and the teacher the depositor" (Freire 1993, p. 53). It is important to see that the point of Freire's critique is not that 'banking' relies on a deficient theory of learning, but that in banking education the student can only appear as object of the teacher's actions, not as a subject in its own right. This is the problem when teaching is enacted as a form of control, which is as much a problem for the kind of teaching Paola Freire was critical of, as it is for the contemporary 'enthusiasm' for teaching where the whole educational process is also a matter of control, aimed at the effective production of pre-specified learning outcomes.

It seems, therefore, that if we are interested in the possibilities for students to be subjects in their own right and not just objects of the intentions and interventions of others-which is not just captured in the idea of education as emancipation but is probably something anyone would agree with who thinks that in education our task is to meet children and young people and equip and encourage them to take up their own lives in meaningful and responsible ways - that teaching is a main stumbling block towards such ambitions. If some, such as Freire, see the teacher as the main culprit, others have even argued that the very 'project' of education is a problem and should therefore be abandoned-a suggestion made particularly by the anti-education movement ('anti-Pädagogik') that emerged in Germany in the 1960s.

Although the learnification of contemporary education comes out of a number of different, only partially related developments (for a discussion see Biesta 2010), it partly stems from the suggestion that teaching limits the freedom of students whereas learning provides opportunities for students to be free and enact their freedom outside of the control of the teacher. That is why teaching - and quite often we nowadays hear 'traditional teaching' — is seen as problematic, outdated and 'of the past,' whereas learning is seen as contemporary and 'of the future.'

When, in my book, I refer to my attempt at the re(dis)covery of teaching as a 'progressive argument for a conservative idea,' I mean it precisely against the background of the situation in which teaching has become positioned at the conservative end of the spectrum-as something we should get away from - and learning at the progressive end. The simple question I raise in the book is whether this positioning of teaching and learning is necessary and inevitable-more simply: whether teaching equals control and learning equals freedom —or whether these positionings need to be reconsidered.

\section{The Symposium}

In the contributions to this symposium I have not so much asked my colleagues to review my own attempts at the re(dis)covery of teaching, as that I have invited them to take up the question whether and, if so, how teaching should be discovered, leaving open the possibility that they may see less of a need for this or perhaps see different avenues and reasons than what I have put on the table in my book. I have not just done so because I believe that everyone has the freedom to make up their own mind-which also means that they should 
make up their own mind—-but also because what should 'bind' us as an intellectual field or discipline are common questions, and not common answers.

\section{A Re(dis)covering Teaching}

Part of my own engagement with the question, centres on the idea that teaching — and any intervention from the 'outside' - is only a limitation of the student's freedom if we think of (such) freedom as 'sovereignty,' as Arendt (1977) has put it, that is, an understanding of freedom as the total absence of influence from the 'outside.' (Isiah Berlin calls this 'negative freedom' - see Berlin 1958.) The question I ask in relation to this is what might happen if our existence as subject is precisely not a matter of being disconnected from everything and everyone that is outside of us, but rather is about being in an ongoing state of 'dialogue' with what and who is other. The question I ask, in other words, is what might happen if we start from the idea that our subject-ness is not constituted from the insideout - from our needs or desires, for example, or from our intentions or our acts of sensemaking - but rather emerges from the outside-in, as a response to what speaks to us, to what addresses us, calls us and, through this, calls us forth, calls us into existence and into the world. The proper name for this address, so I suggest in the book, is teaching, and it is the significance of this idea of teaching and, more specifically, the significance of this encounter with the experience of 'being taught,' that I seek to re(dis)cover in the book.

I develop my own line of thought in five chapters. In chapter 1, called 'What is the educational task?', I suggest that the 'business' of education is not-or not so much, or not primary, or not ultimately - to make students learn, but to arouse in them a desire for wanting to exist in the world as subject. I describe the existence of the individual as subject with the admittedly awkward term 'grown-up-ness,' not in order to suggest that our existence of subject is a question of development and maturation, but to denote a particular 'quality' of what it means to exist as subject.

This is a way of existing where we do not simply pursue our own desires, or any desires that emerge in us, but keep asking the question whether what we desire is what we should be desiring; whether, in what way and to what extent our desires are going to help or hinder in living our own life and our life with others well, on a planet that has limited capacity for fulfilling everything we may desire from it. Existing as subject or, better, trying to exist as subject is therefore about being in the world-in dialogue with what and who is otherwithout thinking or positioning ourselves in the centre of the world. (This particular formulation comes from Philippe Meirieu—see Meirieu 2007, p. 96.)

When, in chapter 2, I raise the question how we might free teaching from learning, I do so not just to question the far too strong and far too exclusive connection between teaching and learning that can be found in contemporary educational discourse and practice-I make the point that it often looks as if teachingandlearning has become one word-but also because I think that the modern emphasis on learning precisely runs the risk of putting the student in the centre of the world. While there is definitely a place for learning in our lives, and hence also in education, I argue that learning is not the be all and end all of our human existence, but only one of the many ways we can exist in and with the world. Hence, I suggest that education has the task to open up other existential opportunities for studentsexistential opportunities beyond learning. Interestingly, as I show through a discussion of some of my own teaching experiences, the significance of such opportunities often only 
comes into view if we deliberately take learning away from teaching, if we bracket learning — hence the chapter's title 'Freeing teaching from learning.'

Chapter 3 pursues this line in more detail by asking whether as human beings we are first and foremost meaning making beings. Whether, in other words, our capacity for signification is (at) the centre of the self and is the way in which we bring ourselves into the world. I see signification as a key dimension of learning-where we try to make sense of the natural and social world 'outside' of ourselves, where we try to comprehend the world-but also focus on signification because it plays such a key role in constructivist conceptions of learning; conceptions that have contributed considerably to the turn away from teaching towards learners and their learning.

Through a close-reading of work from Emmanuel Levinas I explore the opposite line of thought, one that suggests - with a favourite line from Zygmunt Bauman - that morality is 'the first reality of the self.' This does not mean that we are first and foremost moral beings. The point is more existential in that it is only when we meet (a) responsibility we begin to realise that we matter in that situation - that it matters that $I$ am there; we realise, in other words, that we have the freedom to take up this responsibility, to respond to it, or walk away from it. The moment where someone or something 'outside' of us calls us-which we can call the moment of 'being taught'-is the moment where our subject-ness comes 'into play,' where I meet the world and myself in relation to the world. Hence, Levinas helps to see the altogether different possibility: where teaching is not an obstruction to my existence as subject but the very occasion for it.

In chapter 4 I continue this line through a discussion of three 'positions' in the tradition of emancipatory educational theory and practice: critical pedagogy, the work of Paola Freire and that of Jacques Rancière. The discussion centres around a contradiction at the heart of critical pedagogy, namely the ambition to emancipate other human beings by providing them with knowledge about the forces that prevent them from having an accurate understanding of their own (social) condition. The critical teacher thus gives this knowledge to their students in order to set them free but, in doing so, encounters the educational paradox that Kant was already well aware of: namely that the way towards freedom starts with unfreedom, with the teacher who tells the student what is really going on.

Paulo Freire is one of the authors within the critical tradition who was acutely aware of this contradiction. His solution for the problem was to get rid of the teacher-overcoming the student-teacher contradiction, as he puts it-and turning education into a joint praxis, a joint process of knowledge generation of student-teachers and teacher-students. Whereas Freire thus seems to provide a further argument for doing away with the teacher in education that aims for emancipation, it is interesting that Rancière takes the opposite way, where he disconnects emancipation from knowledge but retains a crucial role for the teacher-hence an emancipatory schoolmaster who is ignorant, who has no knowledge to give to 'produce' emancipation but rather is there in order to remind students, again and again, that they are subjects, that they have to lead their own lives and cannot shift this responsibility to anyone else.

In the fifth and final chapter of the book I zoom in on this 'teacherly' gesture, by suggesting that teaching that is interested in the subject-ness of the student constantly needs to 'refer' to this subject-ness, constantly needs to approach the student $a s$ if he or she is indeed a subject, as it is only doing this that paves the way for the student towards their own subject-ness, their grown-up being. Parents do this when they speak to their new born baby, not because they want to stimulate the baby's linguistic development but because they are encountering the baby as a subject-against all the evidence in front of them. 
Teachers, if they are interested in emancipation, need to constantly invent ways of doing the same, which, if we just look at the facts in front of us - the empirical information, the diagnostic data about the student's capacities and capabilities-may look like 'asking the impossible,' as the chapter is called. The impossible, that which goes against the here and now-trusting a child and not knowing what they will do with our trust, for example-is not asking about what is not possible but about what cannot be foreseen as a possibility from the here and now but nonetheless is what we are constantly hoping for: the 'arrival' of the student as subject, in the world but not in the centre of the world.

These are the main 'building blocks' of my attempt at the re(dis)covery of teaching - an attempt that first and foremost speaks in the context of an educational environment that seems to have given up on teaching, but that has a slightly wider significance in that it also speaks in the context of an 'age' in which we are constantly being told, for example by the economic system we have created, that we can have what we want to have and be what we want to be; that we should just be pursuing our desires and should not be asking whether those desires are desirable or not. The rediscovery of teaching is, in this regard, not just an argument within the context of education, but also addresses some of the problems of what Paul Roberts has so aptly characterised as the 'impulse society' we have created (see Roberts 2014).

\section{Giving Teaching Back to Education}

With all of this I ultimately seek to give teaching back to education-which is a very different ambition from giving education back to teachers. My main ambition is to show that teaching is not automatically or necessarily the enemy of the student's freedom and subject-ness, nor that learning is automatically an expression of this freedom, but that the encounter with teaching, with the experience of 'being taught,' provides an important avenue towards a grown-up way of being in the world, without being in the centre of it. To teach with an awareness of this is what I seek to give back to teachers and to education more generally.

\section{References}

Arendt, H. 1977. Between past and future: Eight exercises in political thought. Harmondsworth: Penguin Books.

Berlin, I. (1969[1958]). Four essays on liberty. Oxford: Oxford University Press.

Biesta, G.J.J. 2010. Good education in an age of measurement: Ethics, politics, democracy. New York: Routledge.

Biesta, G.J.J. 2017. The rediscovery of teaching. New York: Routledge.

Freire, P. 1993. Pedagogy of the oppressed, New, revised 20th anniversary ed. New York: Continuum.

Meirieu, P. 2007. Pédagogie: Le devoir de résister [Education: The duty to resist]. Issy-les-Moulineaux: ESF.

Roberts, P. 2014. The impulse society. What is wrong with getting what we want. London: Bloomsbury.

Publisher's Note Springer Nature remains neutral with regard to jurisdictional claims in published maps and institutional affiliations. 